\title{
Comparative Analysis Debt to Equity Ratio and Price to Book Value in State-Owned Enterprises and Private Companies
}

\author{
(Literature Study on Construction and Building Sub Sector \\ Emitents)
}

\author{
Dudi Hendra Fachrudin ${ }^{1,{ }^{*}}$ Ratih Huriyati ${ }^{2,}$ Ikin Solikin ${ }^{3}$ Cahyat Rohyana ${ }^{4}$ \\ ${ }^{1}$ Universitas Pendidikan Indonesia \\ ${ }^{2}$ Universitas Pendidikan Indonesia \\ ${ }^{3}$ Universitas Pendidikan Indonesia \\ ${ }^{4}$ Universitas Pendidikan Indonesia \\ *Corresponding author.Email: komarudin468@upi.edu
}

\begin{abstract}
This research was conducted to determine the comparison of Debt to Equity Ratio (DER) and Price to Book Value (PBV) between State-Owned Enterprises (SOEs) and private companies that have been listed on the Indonesia Stock Exchange in the category of Building Construction Sub Sector. The problem that often occurs was conducting fundraising through debt which causes high DER levels. However, from previous studies it was known that there is a positive relationship between the DER and PBV. This research was conducted qualitatively with analytical descriptive methods and used secondary data obtained from the IDX. The results showed that the DER level of SOEs was greater than private issuers and the industry average, and the PBV of SOEs issuers was smaller than PBV of private issuers and the industry average. The DER level was inversely proportional to the PBV level, and contradict with the previous studies.
\end{abstract}

Keywords: Debt to Equity Ratio; Price to Book Value; Risk and State Owned Enterprises.

\section{INTRODUCTION}

Finance and how it is managed can be the main determinant of strategic success. From the perspective of the shareholders, what is important is the ability to make money from the business because it determines the ability to pay dividends in the short term and reinvest for the future (which, in turn, must in the allowing of the flow of dividend payments in the future). The flow of funds (cash flow) that occurs in a company is the flow of funds in and out of (cash) in the company concerned. The funds that enter the company are funds that come from corporate funding sources, both internal and external sources while the funds coming out of the company are operating funds or losses of the company. The combination of funding sources in a company is often called the funding mix. The structure that forms the composition of the long-term debt financing mix and own capital is called the capital structure. The capital structure strategy is important. It is caused that the companies use debt or equity (stocks) to carry the consequences of risk and return. If the company uses debt, then the company will get benefits in the form of tax savings (tax saving). In the other hand, the use of debt will also pose a risk because of a fixed burden. The source of funds used is essentially the composition of funds or the company's capital structure. Reference [1] state that efficient composition can reduce the capital costs by reducing the capital costs directly to increase economic return net and firm value. The optimal composition can be sought by trial and error based on experience. Furthermore, the traditional approach states that there is an optimal capital structure for each company $[2,3]$.

There are 23 State Owned Enterprises (BUMN) listed on the Indonesia Stock Exchange (IDX) for the 20142017 period. By going public, SOEs will of course become more independent in funding so that they are less 
dependent on the government and with the increase in company capital, of course, company growth can be faster and better [4].

The Deputy Minister of Restructuring and Business Development at the Ministry of SOEs Aloysius Kiik Ro said that the "pre-financing" in funding scheme was often chosen by several contractors caused the debt / liability to equity ratio (DER) of the property and construction sector SOEs to be relatively high. It can be seen in developing the infrastructure, for example toll road, the contractor bailed out the initial costs, including for land acquisition. The scheme is known as pre-financing. Aloysius explained that contractors often borrow large amounts of funds to encourage development projects to be carried out immediately. DER is an indicator that shows the ability to pay a company's debt. The lower value of the DER indicates that a company has a good ability to repay loans [5]

The problem of the research is to know the comparison of the behaviour in capital structure management in SOEs and private companies in increasing the value of their companies. Therefore, the authors analyze the level of debt to equity ratio (DER) and price to book value (PBV) of the two types of companies listed in the Construction and Building SubSector listed on the IDX.

\section{1Corporate Financial Strategy}

Reference [6] states that there are three major problems facing organizations :

1. Managing for value, relating to creating value for shareholders or ensuring the best use of public money, play an important consideration, and responsibility of, managers;

2. Funding strategic development that becomes the nature of the funding is appropriate for the type of strategy and vice versa. It is also related to balancing business and financial risks;

3. The financial expectations of stakeholders and expectations will differ from stakeholders and in relation to different strategies. This will influence managers in the development and implementation of strategies.
The relationship between them can be seen in fig.1 .

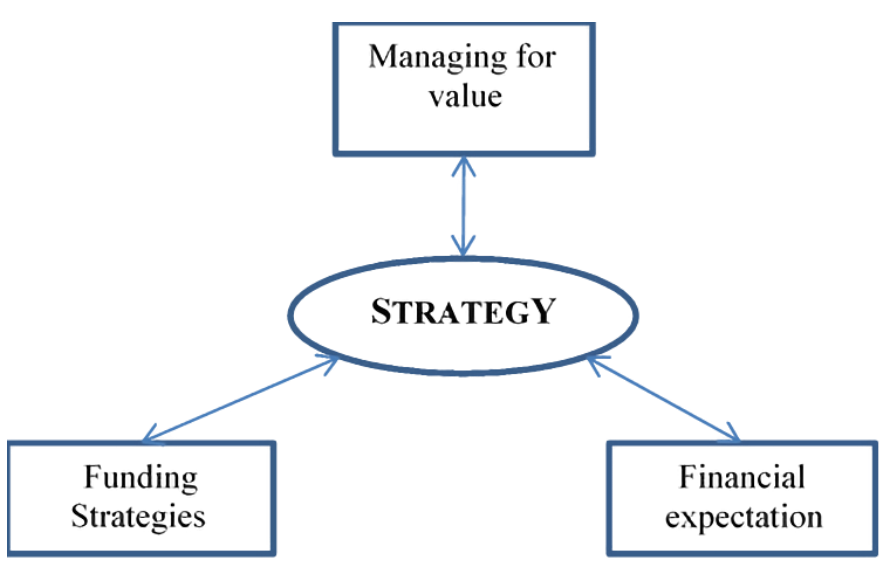

Figure 1 Strategy and people.

Source :Johnson, et al.2005

\subsection{Capital structure.}

Reference [7] states that the phrase capital structure refers to the relative mix of debt and equity securities in the long term financial structure of a company. The structure that forms the composition of the long-term debt financing mix and own capital is called the capital structure. The capital structure strategy is really important. It is caused that the companies use debt or equity (stocks) carry the consequences of risk and return.

\section{3Debt to Equity Ratio (DER)}

Reference [8] argues that the debt to equity ratio illustrates the extent to which owner's capital can cover the debts to external parties. It means that the smaller the ratio is, the better for the company is. Meanwhile according to [9] the debt to Equity Ratio is the ratio which is the ratio between debt and equity. It can be said that the higher the ratio is, the higher the risk of company bankruptcy is. In addition, [10] said that DER is a balance between the debts owned by the company with its own capital. The higher the ratio means that there is less own capital compared to the debt. Debt to Equity Ratio (DER) using the following formula: total debt divided by equity [8].

\section{4The value of the company.}

According to [11], company value or also known as the company's market value is the price that potential buyers are willing to pay if the company is sold. According to [12] market value is how to manage assets efficiently in an effort to improve financial performance and firm value. One of the main duties of the manager is to increase or maximize the value of the company which shows the value of various assets owned by the company and the securities that it has issued. The price per share 
divided by the book value of equity per share equals the business value (price to book value ratio).

\subsection{Research on the effect of debt to equity ratio on ccompany value.}

There have been many studies that related to debt ratio (DER) on firm value (PBV) among others. High DER shows a large debt value, with a large debt, where the debt can be used as capital to rotate the company's activities to earn profits which in turn will increase the value of the company [13]. Reference [14] said that each company has an optimal capital structure, which is expressed as a combination of debt, preference, and equity usually causes maximum stock prices. So, a company that wants to maximize value will estimate its optimal capital structure. The capital structure can be measured by Debt to Equity Ratio and has a significant effect on firm value (PBV). [13-16]. Reference [14], $[17,18]$ stated that the relationship obtained between DER and PBV is positive. A positive correlation value indicates that the relationship that occurs between the DER and PBV variables is unidirectional. It means that the higher the Debt to Equity Ratio is, the higher the Price to Book Value is.

\section{6 Issuers of Building Construction Subsector listed on the IDX.}

Following is the display of building construction subsector companies listed on the Indonesia Stock Exchange on 30 September 2018.

Table 1. Issuers List of Building Construction Subsector

\begin{tabular}{|l|l|l|l|}
\hline No. & Code & \multicolumn{1}{|c|}{ Name of the Issuer } & $\begin{array}{c}\text { Recording } \\
\text { Date }\end{array}$ \\
\hline 1 & ACST & Acset Indonusa Tbk & $24 / 06 / 2013$ \\
\hline 2 & ADHI & Adhi Karya (Persero) Tbk & $18 / 03 / 2004$ \\
\hline 3 & BKDP & Bukit Darmo Property Tbk & $15 / 06 / 2007$ \\
\hline 4 & CSIS & $\begin{array}{l}\text { Cahayasakti Investindo Sukses } \\
\text { Tbk }\end{array}$ & $10 / 05 / 2017$ \\
\hline 5 & DGIK & Nusa Konstruksi Enjiniring Tbk & $19 / 12 / 2007$ \\
\hline 6 & IDPR & Indonesia Pondasi Raya Tbk & $10 / 12 / 2015$ \\
\hline 7 & JKON & $\begin{array}{l}\text { Jaya Konstruksi Manggala } \\
\text { Pratama Tbk }\end{array}$ & $04 / 12 / 2007$ \\
\hline 8 & MTRA & Mitra Pemuda Tbk & $10 / 02 / 2016$ \\
\hline 9 & MYRX & Nusa Raya Cipta Tbk+D5 & $31 / 10 / 1990$ \\
\hline 10 & NRCA & Nusa Raya Cipta Tbk+D5 & $27 / 06 / 2013$ \\
\hline 11 & PBSA & Paramita Bangun Sarana Tbk & $28 / 09 / 2016$ \\
\hline 12 & PTPP & Pembangunan Perumahan Tbk & $09 / 02 / 2010$ \\
\hline 13 & SKRN & Superkrane Mitra Utama Tbk & $11 / 10 / 2018$ \\
\hline 14 & SSIA & Surya Semesta Internusa Tbk & $27 / 03 / 1997$ \\
\hline 15 & TOPS & Totalindo Eka Persada Tbk & $16 / 06 / 2017$ \\
\hline 16 & TOTL & Total Bangun Persada Tbk & $25 / 07 / 2006$ \\
\hline 17 & WEGE & $\begin{array}{l}\text { Wisaya Karya Bangunan Gedung } \\
\text { Tbk }\end{array}$ & $30 / 11 / 2017$ \\
\hline 18 & WIKA & Wijaya Karya (Persero) Tbk & $29 / 10 / 2007$ \\
\hline 19 & WSKT & Waskita Karya (Persero) Tbk & $19 / 12 / 2012$ \\
\hline
\end{tabular}

Source :Indonesia Stock Exchange, 2019

Table 1. showed that the building construction subsector companies listed on the Stock Exchange amounted to 19 listed companies in it registered 4 stateowned companies namely PT Adhi Karya (Persero) Tbk, PT PP (Persero) Tbk, PT Wijaya Karya (Persero) Tbk and PT Waskita Karya Persero) Tbk. and the remaining 15 are private companies.

\subsection{State Owned Enterprises}

SOEs are formed by Law Number 19 of 2003 concerning State-Owned Enterprises. According to Law No. 19 of 2003, that business entities which all or most of their capital are owned by the state through direct participation from the separated state assets; the Company, hereinafter referred to as Persero, was SOEs in the form of a limited liability company whose capital was divided into shares which are all or at least $51 \%$ (fifty one percent) of its shares owned by the Republic of Indonesia whose main purpose is to pursue profit; publicly listed company, hereinafter referred to as open corporation.

\section{METHODS}

The research method used was qualitative with analytical descriptive methods to verify conditions in the field. The data source used was secondary data in the form of literature related to issuers on the IDX, DER, and PBV.

\subsection{Research subjects}

The research subject was a Summary of the Performance of Listed Companies in the Construction and Building Subsector position conducted on 30 September 2018. The population consisted of 19 listed companies, both state-owned and private, and taken as research samples. However, there were two companies that didn't display the data. Then, the samples were carried out on 17 companies' performance reports.

\subsection{Research Objectives}

Based on the background of the research and identification of the problems that has been described, the objectives of this research are to find out: 1) how the DER level of SOEs issuers is compared to private company issuer and the industry DER level in the Building and Construction Sub Sector; 2) how the PBV level of SOEs listed companies compares with PBV level of private company issuer and the PBV industry level in the Construction and Building Sub Sector; how the SOEs and private market capitalization in the industry; how is the effect of DER on PBV from SOEs and private company. 


\section{RESULTS AND DISCUSSION}

Data summary from building construction sub-sector obtained from September 2018 was 19 companies, but only 17 have been published, 2 from PT Hanson International Tbk and PT Superkrane Mitra Utama Tbk. have not been published and the results of data processing as in Table 2. bellow:

Table 2. Summary of Listed Company Performance Building Construction Sub-sector as of 30 September 2018

\begin{tabular}{|c|c|c|c|c|c|c|}
\hline No & Code & ISSUER & $\begin{array}{c}\text { Market } \\
\text { capitali- } \\
\text { zation ( } \\
\text { billion) }\end{array}$ & $\%$ & PBV & DER \\
\hline 1 & ACST & $\begin{array}{l}\text { Acset } \\
\text { Indonusa Tbk }\end{array}$ & 1.099 & 0,94 & 0,73 & 4,90 \\
\hline 2 & ADHI* & $\begin{array}{l}\text { Adhi Karya } \\
\text { (Persero) Tbk }\end{array}$ & 5.800 & 4,98 & 0,95 & 3,64 \\
\hline 3 & CSIS & $\begin{array}{l}\text { Cahayasakti } \\
\text { Invenstindo } \\
\text { Sukses Tbk }\end{array}$ & 593 & 0,51 & 2,85 & 0,9 \\
\hline 4 & DGIK & $\begin{array}{l}\text { Nusa } \\
\text { Konstruksi } \\
\text { Enjiniring } \\
\text { Tbk }\end{array}$ & 277 & 0,24 & 0,39 & 1,32 \\
\hline 6 & JKON & $\begin{array}{l}\text { Jaya } \\
\text { Konstruksi } \\
\text { Manggala } \\
\text { Pratama Tbk }\end{array}$ & 6.500 & 5,58 & 2,71 & 1,02 \\
\hline 7 & MTRA & $\begin{array}{l}\text { Mitra } \\
\text { Pemuda Tbk }\end{array}$ & 294 & 0,25 & 2,12 & 1,04 \\
\hline 8 & NRCA & $\begin{array}{l}\text { Nusa Raya } \\
\text { Cipta } \\
\text { Tbk+D5 }\end{array}$ & 1.033 & 0,89 & 0,87 & 0,92 \\
\hline 9 & PBSA & $\begin{array}{l}\text { Paramita } \\
\text { Bangun } \\
\text { Sarana Tbk }\end{array}$ & 975 & 0,84 & 1,77 & 0,22 \\
\hline 10 & PTPP* & $\begin{array}{l}\text { ParamitaP } \\
\text { (Persero) Tbk }\end{array}$ & 14.000 & 12,0 & 0,95 & 2,19 \\
\hline 11 & Myrx & $\begin{array}{l}\text { Hanson } \\
\text { International } \\
\text { Tbk }\end{array}$ & 9.364 & 8,03 & 1,19 & 0,47 \\
\hline 12 & SSIA & $\begin{array}{l}\text { Surya } \\
\text { Semesta } \\
\text { Internusa } \\
\text { Tbk } \\
\end{array}$ & 2.296 & 1,97 & 0,54 & 0,74 \\
\hline 13 & TOPS & $\begin{array}{l}\text { Totalindo } \\
\text { Eka Persada } \\
\text { Tbk }\end{array}$ & 26.497 & 22,7 & 18,59 & 1,71 \\
\hline 14 & TOTL & $\begin{array}{l}\text { Total Bangun } \\
\text { Persada Tbk }\end{array}$ & 2.012 & 1,73 & 1,96 & 1,91 \\
\hline 15 & BKDP & $\begin{array}{l}\text { Bilot Darmo } \\
\text { Property } \\
\text { Tbk. }\end{array}$ & 430 & 0,37 & 0,91 & 0,62 \\
\hline 16 & WIKA* & $\begin{array}{l}\text { Wijaya } \\
\text { Karya } \\
\text { (Persero) } \\
\text { Tbk. } \\
\end{array}$ & 16.998 & 14,5 & 1,1 & 2,7 \\
\hline \multirow[t]{5}{*}{17} & WSKT* & $\begin{array}{l}\text { Waskita } \\
\text { Karya } \\
\text { (Persero), } \\
\text { Tbk }\end{array}$ & 26.808 & 23,0 & 0,99 & 3,78 \\
\hline & & Jumlah & 116.576 & 100 & 40 & 29 \\
\hline & & $\begin{array}{l}\text { Industri } \\
\text { average }\end{array}$ & & & 2,35 & 1,68 \\
\hline & * SOEs & 4 companies & 63.606 & 54,5 & 1,00 & 3,08 \\
\hline & Private & 13 companies & 52.969 & 45,4 & 2,7 & 1,1 \\
\hline
\end{tabular}

The average DER level of SOEs issuers was in 3.08 greater than the average of private issuers (1.1), and industry (1.68). The benefits of using debt for a company can be summarized in several ways: 1) the debt provided tax benefits because interest expenditure can reduce taxes. Tax benefits from debt can also be expressed in terms of the difference between the cost of debt before tax and after tax; 2) the debt can encourage managers to be more disciplined in their investment choices; 3 ) one way to introduce discipline into the investment process is to force the company to borrow money. Therefore, lending creates a commitment to make interest and principal payments. In companies where there is a separation between ownership and management, the debt controls the manager's opportunistic behavior for spending in accordance with his authority (discretionary). Therefore, with the existence of debt, the manager will focus on the activities needed to ensure that debt payments can be met.

Debt does not give debtors the right to vote, so there is no shift in company control. As for some things that are believed to be a burden due to debt include that debt can increase risk because the possibility of the company being unable to meet its fixed payments can even lead to bankruptcy. This condition may occur when the company fails when the cash flow from the operation is insufficient to pay interest. A company is considered bankrupt if the company is unable to fulfill their contractual commitments, even companies that don't have debts can go bankrupt if they are unable to pay their employees salaries.

Debt would increase the potential for conflict between the creditor and agent (in this case represented by the manager). Conflict arose because the company management took the projects at greater risk than predicted by creditors, where the project was at risk would give good results, but the compensation given to creditors (in the form of interest) didn't go up, so that if there was a loss then the creditor would be harmed. Besides, the debt covenant set at the start of the loan is carried out, causing the company to lose any flexibility in terms of potential funding. This contract includes provisions that restrict management's ability to make investment decisions and pay dividends in specific amounts.

The average PBV level of SOEs issuers was 1, smaller than the average private issuer (2.7) and from the industry average (2.35). The bigger the debt, the more risky it was, and was expected to be less attractive to some investors while the weaknesses of using shares as a source of funding were as follows: the issuance of new shares was often responded negatively by the market, because stock prices had fallen. A negative response arose because of the investor's assumption to management. It was caused that the companies were unable to pay interest if they used debt as a result of poor performance; the issuance of shares caused dilution of share ownership which was the reduction in the percentage of share ownership of old owners who didn't have enough funds to buy new shares that had the potency to resist the issuance plan; publishing of shares 
might result in a shift of control. When the issuance of new shares was not followed by a proportionate purchase from the majority shareholder, it could cause a change in company control because stock financing costs would be higher than debt because many involve other parties, such as underwriters, notaries and others. Stock was capital that could guarantee losses suffered by the company, so that shares could increase the credibility of the issuing company.

Then, it can be seen that SOE issuers, although only 4 companies but control $54 \%$ of market capitalization in the construction and building industry sub-sectors, the remaining $45.44 \%$ are from 13 private issuers. The DER level of SOEs issuers was high (higher than the average industry and private issuer). Furthermore, it turned out that the PBV was low (lower than the average private and industrial issuer).

In all organizations, managers need to decide how the organization will be funded and supported by its strategic development. For example, if a company wants to accelerate its growth by acquiring or developing new goods, the financial requirements would be different than if it wants to maintain its current success. However, as is well known, the phenomenon shows that equity issuance is mostly done by public companies, not least in Indonesia. Then, it is interesting to see the background of the strategy. One of the main functions of finance performed by financial managers is to make decisions relating to fundraising activities (financing decision) (Sartono, 2016).

As an institution that carries out economic functions, the capital market plays an important role in overcoming the needs of the funds. Capital market allows companies to issue securities in the form of bonds or shares [18]. In the other hand, the decision of the company in determining the source of funds to be used will produce different impacts or consequences. Besides, meeting capital needs by issuing shares will lead to increased control over management by the company owner. Thus, it can be concluded that the case of SOEs issuers in the construction and building sub-sector in the influence of DER on PBV was different from the results of previous research, the influence between DER and PBV was negative.

\section{CONCLUSIONS}

\subsection{Conclusion}

1. The average DER level of SOEs issuers in the construction and building sub-sectors was greater than the average DER of private company issuers and the industry average. It means that it was alleg-edly because SOEs companies were more confident in debt than private issuers or pre-financing, consid-ering that was a state-owned company
2. The PBV level of SOEs issuers in the construction and building sub-sector was smaller than the average PBV of private company issuers and industry averages. It was presumably because the value of the company was strongly influenced by the level of debt.

3. The SOEs market capitalization in the Building and Construction Sub Sector (4 companies) was $54.56 \%$, the remaining $45.44 \%$ are from 13 private issuers.

4. The Difference from previous researches, the average DER level of SOEs in the Building and Construction Sub Sector was inversely proportional to the PBV level.

\subsection{Limitation}

This study is certainly still very simple due to time constraints, in measuring the level of DER and PB. It has only been seen for one year. Therefore, it is expected to continue with further comprehensive re-search.

\section{REFERENCES}

[1] J. C. Groth and R. C. Anderson, "Capital structure: perspectives for managers,” Manag. Decis., 1997, doi: 10.1108/00251749710170529.

[2] Sartono, "Sartono, R. Agus. 2001. Manajemen keuangan teori dan aplikasi. Edisi 4. Yogyakarta: BPFE.," in Revolusi Industri 4.0: Desain Perkembangan Transaksi dan Sistem Akuntansi Keuangan, 2001.

[3] Hanafi, Manajemen keuangan. Yogyakarta: BPFE UGM, 2004.

[4] H. Pangestu and H. Lukman, "Faktor-faktor yang mempengaruhi firm value pada bumn," J. Paradig. Akunt. Tarumanegara, 2020.

[5] Ipotnews, "Tingginya DER BUMN Properti dan konstruksi karena skema " pre financing,", 2018. https://indopremier.com/ipotfund/newsDetail.php?j dl=Tingginya_DER_BUMN_Properti_dan_Konstr uksi_Karena_Skema_Pre_financing_Pemerinta h\&news_id=98842\&group_news=IPOTNEWS\&ta ging_subtype $=$ KONSTRUKSINONBANGUNAN \&name $=\&$ search $=y \_$general $\& q=D E R \quad$ BUMN Konstruksi\&halaman=1 (accessed Dec. 04, 2018).

[6] G. Johnson, K. Scholes, and R. Whittington, Exploring corporate strategy. England: Prentice Hall, 2005.

[7] W. L. Megginson, Corporate finance theory. Georgia, USA: Addison - Wesley, 1997.

[8] S. S. Harahap, "Analisa kritis laporan keuangan," Teor. Akunt., 2009. 
[9] T. Prihadi, Memahami Laporan Keuangan Sesuai IFRS dan PSAK. Jakarta: PPM, 2012.

[10] S. Sutrisno, "Pengaruh debt to equity ratio (der), capital adequacy ratio (car), non performing loan (npl) dan loan to deposit ratio (ldr) terhadap return on assets (roa) pada bank yang terdaftar di bursa efek indonesia," J. STIE SEMARANG, 2012, doi: 10.33747/stiesmg.v10i3.210.

[11]S. Husnan and E. Pudjiastuti, "Dasar-dasar manajemen keuangan. Yogyakarta: UPP AMP YKPN," Upp Stim Ykpn, 2013.

[12] E. L. C. G. dan P. R. D. Brigham, Intermediate financial management. New Jersey - USA: Prentice Hall, 1999.

[13]B. Rakhimsyah, Leli Amnah dan Gunawan, "Pengaruh keputusan investasi, keputusan pendanaan, kebijakan dividen dan tingkat suku bunga terhadap nilai perusahaan," J. Investasi, vol. 7, no. 1, pp. 31-45, 2011.

[14]E. F. Brigham and J. F. Houston, Dasar-dasar manajemen keuangan (ed.10). 2006.

[15] Taswan, "Analisis pengaruh insider ownership, kebijakan hutang dan deviden terhadap nilai perusahaan serta faktor-faktor yang mempengaruhinya," J. Ekon. dan Bisnis, 2003.

[16]D. Julianti, "Pengaruh rasio hutang (der) dan profitabilitas (roa) terhadap nilai perusahaan (pbv) (studi kasus pada perusahaan manufaktur sub sektor otomotif dan komponen yang terdaftar di bursa efek indonesia periode 2012-2014)," J. Ekon. Univ. Kristen Indones., 2015.

[17] Furniawan, "Pengaruh earning per share, debt to asset ratio, debt to equity ratio dan return on equity terhadap price to book value," Asia Pasicific Jounal Manag. Stud., vol. 6, no. 3, 2019.

[18] Husnan, "Dasar-dasar teori portofolio dan analisis sekuritas edisi ketiga," Yogyakarta UPP AMP YKPN, 2001. 